\title{
THE GROWTH OF MISSIONARY CO-OPERATION SINCE 1910
}

\author{
By JOHN H. RITSON, D.D.
}

Ir is the purpose of this article to give an account of the growth of missionary co-operation since the World Missionary Conference at Edinburgh in 1910. The machinery set up by that Conference was international, and the paper is concerned primarily with missionary co-operation in its international aspects. But since the offices of international missionary co-operation were established in Great Britain, and since the war interrupted international communications and the time of the secretaries of the Continuation Committee of the Edinburgh Conference was in consequence devoted more largely than would otherwise have been the case to the promotion of missionary co-operation among British missionary societies, it is not possible to separate the growth of missionary co-operation in Great Britain from the wider aspects of the subject, though the attempt will be made to keep the two lines of development distinct. The subject of missionary co-operation in North America is treated by Dr Watson in a separate article.

Before the Edinburgh Conference of 1910 practical co-operation at the home base in Great Britain had scarcely been attempted except in the tract, literature and Bible societies. There had been opportunities from time to time for the interchange of experience and the discussion of missionary problems. The London Secretaries' Association, which was founded in 1819 , brought the executive officers of nearly all the English societies into personal touch with each other, and contributed to the most friendly relationships. The missionary conferences, which were held at irregular intervals from 1854 onwards, extended the fellow- 
ship to a wider circle of societies. Those of 1888 in London and 1900 in New York were international in character, and brought into mutual counsel those responsible for administration on both sides of the Atlantic. They also deepened in the Church as a whole the sense of privilege and duty in world evangelization, and gave some vision to the outside public of the importance and fruitfulness of missionary enterprise. While it must be conceded that the conferences in this period were of great value, it must also be admitted that there were grounds for the criticism that the results were not commensurace with the time and energy and money expended on their organization.

The year 1910 marks the beginning of a new era in the history of missions-the era of definite international cooperation. While the planning for the World Missionary Conference was yet in its early stages, in June 1908 a committee of seventeen members-ten from the United Kingdom, five from North America and two from the Continent of Europe-met at Oxford, and after much prayer and earnest deliberation worked out the fundamental principles upon which a conference of permanent value might be held. It was first necessary to acknowledge that there are limits to practical co-operation under present conditions. Outside these limits lay the questions of ecclesiastical polity and dogmatic belief upon which the members of the conference would be seriously divided. In order to avoid these, the committee were compelled to limit their purview to problems arising in non-Christian fields. To attempt to press for co-operation in matters that are divisive would have wrecked the effort to secure united action on common ground. But the failure to cooperate, wherever co-operation was possible without the sacrifice of principle, appeared to be sinful, and it was therefore resolved to plan for conference on subjects which were urgently demanding immediate consideration an which it was possible for various societies to work together. The common ground which remained was quite sufficient 
for thorough and scientific investigation, especially as there were only two years for preparation. In fact the ground was far too extensive to be covered by a single conference, and it was necessary to deal with eight subjects or groups of subjects only. The problems were studied in advance, and reports were presented to the conference, not by individuals but by representative groups of experts working as commissions. These considered statements on matters of vital interest in missionary administration carried with them the common judgment of missionary leaders of many societies, and afforded a foundation for co-operation such as had not previously existed. There is another element. which must always be present if co-operation is to succeedthe realization of 'the fellowship of the Holy Ghost.' It comes by prayer. And it was present at the Edinburgh Conference, which was begun, continued and ended in prayer. It was because of the atmosphere of intercession that the tender plant of co-operation survived, and it is because that atmosphere has been maintained that the plant is now growing to strength and maturity.

The Edinburgh Conference was an amazing gathering. It brought into common study and spiritual fellowship Christian leaders who had been toiling in separate compartments all over the world. As they knelt in prayer it gave them a new vision of the needs of the human race and of the sufficiency of God. But these experiences were not altogether new. The great fact which differentiated the Edinburgh Conference from preceding conferences and made it the beginning of a new era, was that it definitely organized for the perpetuation of its own spirit and work. Its unique feature was the appointment of a Continuation Committee, which at first consisted of ten members from the United Kingdom, ten from North America, ten from Continental Europe and one each from South Africa, Australasia, India, Japan and China-with Dr John R. Mott as chairman and $\mathrm{Mr}$ J. H. Oldham as secretary. To those who have carried the main burden of responsibility in this 
committee the churches owe a great debt. Surely their extraordinary statesmanship, their balanced judgment, their Christian charity and intellectual grip of difficult situations have been gifts of God to further that unity for which the Master prayed. The Continuation Committee faced their task in a spirit of seriousness and of humble dependence on the divine leading. They met as soon as the Edinburgh Conference closed, and having outlined their programme appointed a series of special committees, upon which experts from outside their own number were co-opted, and set them to begin work where the conference had laid it down. Subsequent meetings were held at Bishop Auckland in 1911, at Lake Mohonk (U.S.A.) in 1912 and at The Hague in 1913. Arrangements were well in hand for a meeting at Oxford in 1914, when like a thunderbolt came the outburst of the world war. In the isolation and strife of the two great and conflicting camps into which the nations were gathered a meeting of international character was impracticable, and it seemed at first as though the work of the Edinburgh Conference were going to be wrecked. But in the providence of God the spirit of cooperation weathered the storm. Even in the very years in which the ingenuity and time and talents of the human race have been concentrated on devising or combating instruments of cruelty and destruction, the bonds of union between Christians, set on the uplift and redemption of mankind, have been growing in strength and in number. The officers of the Continuation Committee have continued to direct the investigations of the special committees and to give effect as far as possible to their recommendations; but they have had to act in their own personal capacity, or at most in consultation with some members only of the Continuation Committee. Since August 1914 it has not been possible to do anything with the mandate of the whole body.

The fact that the Continuation Committee was charged to initiate arrangements for the next World Missionary 
Conference if in the meantime no more permanent organization had taken its place implied that there might be many years of work before it. Nevertheless it was obvious from the first that it was a temporary and imperfect instrument for united international action. It was appointed by a conference and represented that conference only. Each year that passed made its authority more remote, and tended to remove its personnel from vital touch with the present-day leaders of the societies. Some members of the original committee died and others resigned, and there was no arrangement for filling vacancies. In order to secure more adequate representation of missionary interests-for it is impossible to represent societies on so small a body -the surviving members co-opted outstanding leaders to fill vacant places, added seven more to the original number of members and appointed $\mathrm{Mr}$ Maclennan to be $\mathrm{Mr}$ Oldham's colleague in the secretariat. These adaptations to changing conditions were only regarded as provisional. The problem of establishing an authoritative international committee as a consulting and advisory (and when requested the executive) organ of missionary societies in all countries was under most urgent and prayerful consideration when the war broke out, and the complications were multiplied. The Continuation Committee as a whole could not meet either to appoint successors to carry on its work or to disband and leave the societies to begin de novo. As there is no authority outside itself to deal with its status, its future must rest in abeyance until conditions permit of a meeting or of consultation between all the surviving members.

But the war has given rise to new problems, and there is urgent need of immediate and united action by a body of men and women in closest touch with the societies and having the international point of view. The American and British missionary conferences, acting through their executives, have therefore appointed an 'Emergency Committee of Co-operating Missions' consisting of eight members from North America and six from Great Britain, with one 
member representing each other country, the missionary societies of which are willing to appoint representatives. As the name implies, this new committee is only provisional. It appears, however, to be the best organization of which present world conditions permit for dealing with international questions as urgency may require. The functions of the committee will be $(a)$ to consult regarding questions affecting the relations between missions and governments in which the missionary societies are jointly interested; (b) to consult regarding the means by which provision may be made for the work of the missions which have suffered through the war; and (c) to correlate constructive plans for meeting the present situation and for dealing with questions in which the missionary societies have a common interest in this crisis. The work of the committee will be largely confidential, and upon its action the future of Christian missions and of the kingdom of God may vitally depend.

One result of the Edinburgh Conference was to show clearly the need for some organization to bring together the missionary societies in Great Britain, corresponding to the conferences which were already in existence in North America and on the continent of Europe. A meeting summoned by the British members of the Continuation Committee at the request of the London Secretaries' Association was held in York during 1911. Delegates were present from forty missionary societies, and it was resolved to hold an annual 'Conference of Missionary Societies in Great Britain and Ireland.' In its spirit and aim and limitations this conference is modelled on that of Edinburgh. The members are appointed by the missionary boards and committees, their number being determined by the amount of ordinary current expenditure among non-Christian peoples.

In order to act as an executive in between its annual meetings the conference appointed a Standing Committee, consisting at first of eighteen and subsequently of twenty-four members, with provision for the 
maintenance of continuity and at the same time change of personnel by the retirement in rotation of one-third of the members each year. The first regularly constituted conference was held at Swanwick in 1912, and was attended by delegates from forty-three missionary societies and organizations, together with fifteen co-opted members. A great step in advance was taken at this gathering. It was resolved to ask the societies to bear the cost of the cooperative work undertaken by the Continuation Committee and by the conference itself, by means of a self-imposed assessment in proportion to their expenditure as calculated in fixing their delegation to the conference. The amount required in the year 1912-3 was at the rate of thirty-one shillings for every thousand pounds of expenditure, though naturally the budget estimate varies from year to year. That the boards and committees, in spite of the strain of their own finances, responded in a most generous way and have carried the whole burden of co-operative finance ever since is the best possible proof of their practical sympathy with the growing movement towards unity of effort in world evangelization. Seven British missionary conferences have now been held since the meeting in York, and it is significant of progress that from year to year the verdict of delegates has been, "This last conference is the best we have ever had.'

The offices of the Continuation Committee were established at Edinburgh for reasons which at the time were decisive. But London, where the great majority of British missionary societies have their head-quarters, was necessarily the place of meeting for the British sections of all the special committees appointed by the Continuation Committee, and as time went on the disadvantages of having offices in Edinburgh when all committees met in London became more and more apparent. London also was obviously the centre of the activities of the Conference of Missionary Societies in Great Britain and Ireland, the responsibilities and work of which increased from year to year. Finally 
questions arising out of the war necessitated such frequent communication with government departments in Westminster that the transfer of the head-quarters of missionary co-operation in Great Britain from Edinburgh to London became inevitable. Accordingly, after consultation in April with Dr Mott and Dr Charles Watson representing the Committee of Reference and Counsel in America, the British Conference of Missionary Societies in June 1918 resolved to establish the head-quarters of missionary cooperation in London, and temporary quarters were rented at 117 Victoria Street, S.W. 1. It is hoped to secure a permanent property, 'Edinburgh House,' to be the centre of the co-operative undertakings, which are growing in size and import from day to day. To achieve this a private

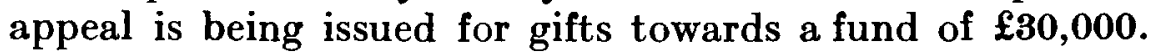
The interest on the capital will relieve the societies of the burden of rent and other items of expenditure until a really attractive scheme for the purchase of a freehold presents itself. In 'Edinburgh House' when it is secured, and meantime in the temporary London offices, accommodation will be provided for the Emergency Committee, and for the Continuation Committee so long as it continues in existence, as well as for the British Conference of Missionary Societies.

The machinery is complex-a Continuation Committee out of gear for the moment, an Emergency Committee running in its place, a Standing Committee of the British Missionary Conference, and under these some twenty special committees all engaged on work of vital importance in the present-day administration of missions. The question arises, 'What are the practical results?' Are they an adequate return to the societies which provide the running expenses? To change the figure, the tree planted eight years ago has grown beyond all expectation and is bearing fruit, but is the fruit commensurate with the cost and trouble of cultivation? 'By their fruits ye shall know them.' That is the test which must be rigorously and justly applied. 
In applying the test it is not necessary to attempt to assign particular results to particular committees. Sometimes an international committee and a national committee have worked on one subject in its wider and more limited aspects. Sometimes an international committee has worked in two sections, one on each side of the Atlantic. In all cases the work has been under a central control, investigations have been co-ordinated and separate lines of study have been made to converge. The methods are yet experimental and call for adaptation, and in any case must continue to be elastic. The supreme question is not, Who has done this or that? but, What contribution has the modern development of co-operation made to the progress of the kingdom of God?

Before attempting to answer this question it is worth while to call special attention to the foundation on which the missionary co-operation which we are about to describe has been built up. The Continuation Committee at its meeting at The Hague in 1913 passed a resolution, the farreaching and vital importance of which the experience of succeeding years has made increasingly manifest. It runs as follows: "The only bodies entitled to determine missionary policy are the churches, boards [i.e. missionary societies] and missions concerned.' The same principle, though never embodied in a formal resolution, has been the basis of the work of the Conference of Missionary Societies in Great Britain and Ireland. This means that the committees mentioned in the present paper, while they meet and consult, never commit themselves to any policy or take executive action except when it is known that they have the approval of the missionary societies concerned. It is the firm and loyal adherence to this principle which has given the missionary societies confidence in missionary cooperation and led to its remarkable growth.

We may now come back to the question of practical results. Missionary co-operation has extended the means of intercommunication between the mission fields and the 
home bases. The Continuation Committee in January 1912 issued the first number of a new quarterly magazine, The International Review of Missions, under the editorship of Mr Oldham, who subsequently secured the assistance of Miss G. A. Gollock. As the organ of the Continuation Committee it aims at the scientific investigation of the problems of the mission field from the widest possible outlook, and provides from quarter to quarter a critical bibliography of missionary books and articles on the growth of the kingdom of God among non-Christian peoples. Other bonds of union between 'at home' and 'abroad' were established when $\mathrm{Dr}$ Mott visited the East in 1912-3 and held a series of conferences. The conference in China resolved to form a Continuation Committee which, if not representative of the societies in the popular sense, is composed of missionaries and Chinese Christian leaders who enjoy the full confidence of their fellow-workers. The conferences in India appointed Representative Councils of Missions in the different provinces and a National Missionary Council, the members of which are more strictly representative. A Continuation Committee was also appointed in Japan. Like the Continuation Committee of the Edinburgh Conference, these bodies are advisory. Their authority rests on the character and experience of their personnel. It is an inestimable gain to have in the great mission fields of the world central organizations which can speak for the whole, view the detailed spheres of the work from the standpoint of the whole and advise as may be required those working at the home bases.

It is no unimportant contribution to progress to have established these means of communication and points of contact between more or less isolated units in missionary propaganda.

This is not the place to describe in detail the work of these bodies in the mission field, which would require a separate article to do justice to it. But one or two illustrations of the important services they are rendering may be 
given in passing. Both the National Missionary Council in India and the China Continuation Committee have prepared important statements on missionary comity, dealing with such matters as the division of territory, arbitration and the transfer of mission agents and of church members. The remarkable measure of agreement which has been reached marks a notable advance in missionary relations. The National Missionary Council after full deliberation passed a series of resolutions on the proposal to introduce a conscience clause in Indian education, and was thus able to express effectively the common missionary mind in regard to an issue that may have a far-reaching effect on Christian education in India. Among the many activities of the China Continuation Committee a Forward Evangelistic Movement has given a powerful stimulus to evangelistic effort throughout China and rendered invaluable service to the churches and missions in undertaking new and larger evangelistic efforts and in the preparation of workers to carry them out.

To return to our main subject, one of the tasks to which the Continuation Committec first turned its attention because of its fundamental nature was the problem of missionary survey and occupation. The commission of the Edinburgh Conference on this subject began the study and gave the results of its investigations in a volume which still remains the best statement in brief compass of the general missionary situation in non-Christian lands. But the commission only touched the fringe of the subject, and committees have been carrying on its work through all the years since 1910. Under the National Council of India the Rev. W. H. Findlay is now engaged in making a survey of missionary work and problems in India which promises in thoroughness and method to surpass anything of the kind yet dreamed of. Other committees are at work surveying missions in China, the Moslem fields as a whole, and the mission fields of the Near East in relation to the upheavals through which they are now passing. The common bases 
of these surveys must be uniform if their comparative results are to be of value. It is necessary therefore that there must be clear and authoritative definition of terms used. To secure this end an international committee on the unification of missionary statistics has gone a long way towards defining terms, which in the past have been used in different senses in different countries and even in the several missions of a single country. The incidence of war only has delayed the practical application of the recommendations made. It is scarcely necessary to dwell on the value of careful and scholarly survey. Just as an appeal to the actual phenomena of nature transformed alchemy into chemistry and astrology into astronomy, so the very foundation of missionary science lies in an accurate and detailed knowledge of facts in their various relations and correlations. The days of empiricism in missions are over, because leaders have learned to co-operate in survey. The days, too, of overlapping in one district and the neglect of another will be brought to an end when the churches, having made their surveys, realize their responsibility in the matter of occupation.

Another committee appointed by the Continuation Committee is concerned with Christian education in the mission field. The American section of the committee has devoted its attention especially to Japan and China, and by deputation and special investigations has helped to further the cause of Christian education in these countries. The British section of the committee has given its attention primarily to conditions in India and Africa. It has called two conferences of representatives of missionary societies in Great Britain to consider the proposal to introduce a conscience clause in Indian education. A notable outcome of the work of the committee is the founding of the Christian College for Women in Madras. No single society, no single community of churches, could have accomplished the task, but in and by co-operation an institution is now established for the higher education 
of women which will have no small part in shaping the destinies of India. A new problem is now under consideration - the educational needs of mass movements in India. The committee is arranging to send experts to study the conditions and needs of the people on the field, in order that they may have first-hand and accurate information for their guidance.

The Committee on Christian Literature on the Mission Field is engaged on a task parallel in importance with that on education. A general survey ${ }^{1}$ of existing organizations producing literature, of the needs of every part of the field not yet provided for and of possible lines of development has already been published. A central committee is pursuing the problem for the whole of India and another for the whole of China, while correspondence is in hand for the organization of other parts of the mission field. It is fully expected that it will be possible to coordinate the activities of the many independent tract and literature societies, to provide healthy literature for the growing number of readers in our schools and churches, and to bring the work under the direct control of the missionary societies, as a part of their essential task and a part for which they are financially and otherwise responsible. There is no hope of providing an adequate stream of firstclass literature for Christians and non-Christians, for men, women and children of all classes and conditions, unless the missionary societies pool their resources of men and talents and money.

Springing out of the work of the committee on Christian literature another committee in Great Britain has been engaged on the task of providing suitable and up-to-date literature to bring to the Jews the knowledge of Christ. Its commission has this year been extended, and it is now to examine the whole situation of the Jews in their dispersion with a view to the wise distribution of missionary

1 Christian Literature in the Mission Field, by John H. Ritson, D.D. Published by the Continuation Committee, I Charlotte Square, Edinburgh. Is. net. I9r 5.

55 
forces. The war has given extraordinary urgency to the task in the Near East and particularly in Palestine, and it is nothing less than providential that common study and common action are now practicable.

In Great Britain there has been established an Advisory Board of Medical Missions, which has summoned to its help a body of distinguished surgeons and physicians and missionary administrators and is able to give invaluable advice in shaping the policy of medical missions, particularly in matters of training and equipment and medical education in the mission field. It has given special attention to the question of Christian medical education in China, and has been able to render assistance in the attempt to establish a first-rate Christian medical college, teaching in Mandarin, at Tsinanfu.

Co-operation at the home base is a matter of national rather than international oiganization, and the committees dealing with this subject are those appointed by the Conference of Missionary Societies in Great Britain and Ireland. A committee has been appointed by the conference to consider increased 'Economy and Efficiency in Administration.' In consequence of the war it has scarcely done more than look down some of the avenues of useful service. By mutual counsel and centralized action much may be accomplished in improving methods of book-keeping and finance, in insurance, in purchasing medical and other supplies, in securing passages and freightager and common codes for cabling.

Another committee on 'Co-operation at the Home Base' contemplates the using of outstanding missionaries of each society for the benefit of all, economy in deputational expenditure by the holding of joint meetings in selected centres, joint action in schemes of publicity, especially in the secular press, and the preparation and publication of pamphlets and books of common value to all societies alike. This committee is only yet looking out upon its possibilities of development, and the lines are 
so obviously right that business men may well say, 'Why was not this done sooner?'

Two other new committees are appointed to deal with ' The Missionary Appeal to Working Men and Women' and 'Recruiting for the Mission Field.' The isolation of the masses of the people from organized church life are the raison d'être of the former, and the need for labourers to go forth into the harvest gives urgency to the work of the latter, while the demobilization of men and women engaged in the war makes the work of both committees timely.

Considerable results have already been achieved by cooperation in the training of missionaries. A Board of Study has been established corresponding to the Board of Missionary Preparation in North America, and for some years summer schools and courses of lectures have been arranged in Oxford, Cambridge, Birmingham, London and elsewhere. A bibliography of suitable literature, brought up to date by quarterly bulletins, has been issued for the use of candidates for the mission field. Many students have been materially helped through private correspondence conducted by the secretaries of the board, and the theological colleges of the churches have been visited in order to stimulate the specific training of missionaries. The founding of an interdenominational college is proposed, not to take the place of denominational institutions but to provide supplementary courses in such subjects as phonetics, language, non-Christian religions, ethnology, peragogics and hygiene, and to bring the students of various churches into fellowship before they proceed to the mission field.

Another committee has given itself to the consideration of the establishment on a co-operative basis of training schools for the further preparation of missionaries after they arrive in the field, and is in correspondence with language schoois already at work.

When we turn finally to the war a host of problems present themselves which the missionary societies can deal with only in co-operation. The removal of German 
missionaries from the British Empire imposes on the missionary societies the large and difficult task of providing for the continuance of the work hitherto carried on by German missions. In other areas the war has broken up Christian communities, scattered Christian teachers and closed schools and hospitals. The task of rebuilding and reconstruction is so great that it can be successfully accomplished only by regarding the problem as a whole and ascertaining all the important facts bearing on it. Had the present international missionary organization not been in existence it would have been impossible to meet so difficult a situation. All the facts are being carefully collected and the necessary data will be available for the Emergency Committee when it is able to meet. In the meantime many conferences have taken place which have helped towards an understanding of the problem and have indicated certain lines along which a solution must be sought.

Other large questions have arisen involving relations with governments. Almost every belligerent government as a result of the war has been brought up against the problem of missionary work carried on by missionaries of enemy nationality. The problem widened into that of the conduct of missionary and particularly educational work by missionaries of alien nationality, whose political sympathies might make co-operation between them and the government under whose rule they were working difficult. The British government especially found itself confronted with questions of this kind, and the Standing Committee of the Conference of Missionary Societies was invited to confer with the Government on the subject. As a result of these discussions certain dangers which it was feared might prejudice missionary work in the future were averted. A statement of the proposed policy of the Government was submitted to the Conference of Missionary Societies last June, which seemed to the conference free from objection and which held out the promise of friendly co-operation 
in the future between the Government and the missionary societies in finding a solution of any difficulties that may arise. It may be said without hesitation that this result could not have been reached had co-operation between the missionary societies not reached its present stage and the way been prepared for prompt and hearty united action.

Another large question calling for common action is the necessity, in connexion with political changes in the Near East and in any settlement of the future of tropical Africa, as well as in other parts of the world, of securing alike for the native population and for foreigners full religious toleration and freedom for missionary work. A number of treaties by which such liberties have been secured in the past will lose their validity as a result of the war and it is essential that in any new acts which take their place the necessary safeguards of religious toleration and missionary freedom should find a place. These questions have received the close attention of the Standing Committee, and advantage was taken of a visit of Dr Mott and Dr Charles Watson to Great Britain to arrive at a full understanding as to common action by the British and American missionary conferences. An opportunity also presented itself of conference with the Committee of the Paris Missionary Society on the subject and thus of securing a still further measure of concerted action.

The securing of passports for women missionaries, whose return to the mission field was urgent but was prevented by the restrictions on the travelling of women, is another matter in which the missionary societies have found how much more can be gained by united and co-ordinated action than by the independent efforts of forty or fifty different missionary organizations.

In these matters, and in others which cannot be fully gone into here, it has been demonstrated that only by acting together can the missionary societies deal effectively with the many large problems with which the war has confronted 
them. It has also been shown how ready the British government is to deal sympathetically with missionary interests when it has to do with a single body acting on behalf of the different missionary societies. The value of co-operation, the absolute necessity for it, has never received such vindication as in these new problems which involve relations between missions and governments and can be rightly solved only if a proper understanding is reached.

It is not possible to exhaust in the space of a single article the aims and achievements of the organizations for co-operation which came into being in 1910. The greatest and most lasting results can never be set down in writing. Neither figures nor words can express the blessings which have resulted from common fellowship in Christian work, from the enlarged outlook, from the new habit often unconsciously acquired of viewing the work of a particular society in relation to the wider progress and needs of Christ's kingdom, and from the united intercession with which all the work of co-operation has been begin and continued. Like the translators of King James's version of the English Bible, those who have come together as fellowlabourers have been able to say, 'All sectarian influences were banished, and all hostilities were mute.' Co-operation in foreign missions is now established in our midst, established to the great benefit of those who unite and to the furtherance of the kingdom of God upon earth. It has come to stay, and doubtless it will bear fruit and increase even as 'the word of truth.' Perhaps one reward for foreign missionary enterprise will be that the churches at home will discover in that part of their task methods by which they can safely come together in the great problems of the homeland which they are now facing in disunity if not in actual jealousy one of another.

JohN H. RITSON 